\title{
Mengungkap Isyarat-Isyarat Sains Dalam Hadis Nabi
}

\section{(Revealing Science Signs in the Prophet's Hadith)}

\author{
Yuri Indri Yani ${ }^{1}$, Yuliharti ${ }^{2}$, Kholil Syu'aib ${ }^{3}$, Mardinal Tarigan $^{4}$, Paini $^{5}$ \\ 1,2,3UIN Suska Riau, ${ }^{4}$ STIT Hamzah Al-Fansuri Sibolga Barus, ${ }^{5}$ SMA Negeri 1 Sibolga \\ 1yuriindriyani250@gmail.com, ${ }^{2}$ yulihartiabbaas245@gmail.com, ${ }^{3}$ kholil.syu'aib@uin-suska.ac.id, \\ 4mardinaltarigan2020@gmail.com, 5painisembiring80@gmail.com
}

DOI: $10.29240 /$ alquds.v5i1.2512

Submitted: 2021-02-15 | Revised: 2021-05-01 | Accepted: 2021-05-31

\begin{abstract}
This study aims to explore the concept of the signs conveyed by the Prophet through his words relating to science or science. In addition, it also presents traditions that give a signal for humans to always develop knowledge in carrying out the duties of the caliph on earth. The method used in this study is in the form of pure literature with the techniques used in collecting data based on documentation through written legacy evidence such as writings or manuscripts, archives, books on opinions, theories, concepts and arguments and related laws. with the formulation of the study problem. Based on this study, it is found that the hadith is very important for humans to study and research the universe and its contents and always instructs humans to develop knowledge for the advancement of human civilization. Where long before the discoveries in the field of science and technology were discovered or scientifically proven, the Messenger of Allah had hinted at his people through his words.
\end{abstract}

Keywords: Facts; Science; Hadith; Prophet

Abstrak. Penelitian ini bertujuan untuk menggali konsep tentang isyarat-isyarat yang disampaikan oleh Nabi melalui sabdanya berkaitan tentang sains atau ilmu pengetahuan. Selain itu juga menyajikan hadis-hadis yang memberikan isyarat bagi manusia untuk senantiasa mengembangakan ilmu pengetahuan dalam mengemban tugas khalifah di muka bumi. Metode yang digunakan dalam penelitian ini adalah berupa kepustakaan murni dengan teknik yang digunakan dalam mengumpulkan datanya berdasarkan dokumentasi melalui buti-bukti peninggalan yang tertulis seperti tulisan atau manuscript, arsip-arsip, buku-buku tentang pendapat, teori, konsep maupun dalil dan hukum yang berkaitan dengan rumusan masalah kajian. Berdasarkan penelitian ini ditemukan bahwa hadis sangat mengisyaratkan bagi manusia untuk mengkaji dan meneliti alam semesta beserta isinya dan senantiasa memerintahkan manusia agar mengembangkan ilmu pengetahuan untuk kemajuan peradaban manusia. Dimana jauh sebelum penemuanpenemuan dalam bidang ilmu pengetahuan dan dan teknologi berhasil ditemukan atau 
dibuktikan secara ilmiah, Rasulullah telah mengisyaratkan kepada umatnya melalui sabdasabdanya.

Kata kunci: Isyarat; Sains; Hadis; Nabi

\section{Pendahuluan}

Islam merupakan agama yang kompleks, dimana dalam Islam segala aspek kehidupan manusia senantiasa diatur dengan didasarkan pada dua pedoman yakni Al-Qur'an dan Hadis Nabi SAW. Salah satu aspek kehidupan manusia yang diatur olehnya adalah aspek sains atau ilmu pengetahuan. Walaupun tidak sepenuhnya dirincikan oleh Allah dan Rasul tentang aspek sains atau ilmu pengetahuan ini, namun di dalam Al-Qur'an maupun Hadis Nabi sudah sangat banyak mengisyaratkan tentang perintah untuk mengkaji serta mengembangkan sains, ilmu pengetahuan dan teknologi.

Islam dan sains merupakan dua aspek yang saling berkaitan dan berpengaruh terhadap kehidupan manusia. Hubungan kedua aspek tersebut saling memberikan kekuatan kepada manusia dan mengarahkan pada peradaban yang maju dan berkembang. Pada aspek ajaran Islam, manusia mempunyai pedoman dalam melakukan suatu upaya untuk mencapai tujuan tertentu terutama dalam aspek batiniah (spiritual) sedangkan sains dapat memberikan manusia suatu peralatan atau penemuan-penemuan yang dapat mempercepat kemajuan dan membawa revolusi lahiriah (material) bagi manusia. Sains dapat mengakomodir pikiran dan akal manusia sedangkan Islam mengakomodir perasaan dan jiwa manusia. ${ }^{1}$

Berdasarkan fakta di lapangan mengungkapkan bahwa umat non muslin yang lebih giat mengembangkan sains dan teknologi. Mereka mampu memanfaatkan akal dan alam semesta untuk memperoleh dan mengembangkan ilmu pengetahuan. Pada bidang sains, banyak penemuan dan peralatan yang berhasil diciptakan oleh ilmuwan barat dimana hasil penemuan tersebut ketika ditelusuri ternyata sudah terlebih dahulu diisyaratkan oleh Rasulullah melalui sabda-sabdanya. Berdasarkan fakta sejarah, umat Islam pernah menjadi pusat perdaban dunia. Hal ini dikarenakan pada masa itu umat Islam dan IlmuwanIlmuwan Islam senantiasa menggali dan mengembangkan ilmu pengetahuan dan

\footnotetext{
${ }^{1}$ Restiana Mustika Sari \& Yudi Setiadi, "Keselarasan Islam dan Sains”. Ushuluna: Jurnal Ilmu Ushuluddin, 3(2), 1-26. 2020. https://doi.org/10.15408/ushuluna.v3i2.15193.
} 
teknologi sehingga kemajuan semakin pesat khususnya dalam bidang Kedokteran, Ekonomi, Sosial, Arsitektur, dan lain-lain. ${ }^{2}$

Konsep pengembangan ilmu pengetahuan dalam Al-Qur'an maupun Hadis bersifat komprehensif dan integratif. Ilmu agama dan pengetahuan tidak ada pemisahan dalam Islam. Kedua ilmu tersebut adalah berasal dari Allah yang dianjurkan dan diperintahkan untuk digali serta dikembangkan guna mencapai kemajuan umat manusia. Nabi Muhammad SAW sebagai Nabi terakhir bagi umat Islam dan memiliki kelebihan (mukjizat) terbesar yaitu Al-Qur'an yang diberikan oleh Allah SWT. Segala apa yang dilakukan oleh Nabi dilandaskan pada Al-Qur'an dan menjadi suri tauladan bagi umat Islam hingga sekarang. Nabi Muhammad juga diajarkan langsung oleh guru yang Maha Benar yakni Allah SWT dalam segala halnya. Hal ini menjadi dasar bahwa Nabi telah diberikan ilmu oleh Allah tentang berbagai hal termasuk dalam bidang sains dan ilmu pengetahuan. Hasil penemuan-penemuan ilmiah yang telah ditelusuri ternyata sesuai dengan sabdasabda Nabi. Saat ini, ilmu pengetahuan yang bertolak belakang dengan Al-Qur'an dan hadis Rasulullah disebabkan oleh beberapa kemungkinan yaitu (1) kesalahan dalam menafsirkan atau menginterpretasikan wahyu Allah dan Sabda Rasulullah; (2) sifat ilmu pengetahuan yang akumulatif yakni selalu mengalami perubahan sesuai dengan perkembangan zaman dan selalu mengalami proses penyempurnaan. ${ }^{3}$

Salah satu tokoh yang mengkaji tentang sains dalam hadis yaitu Mehdi Golshani. Beliau merupakan seorang tokoh fisikawan yang aktif dan produktif dalam melakukan riset dan berfokus pada beberapa masalah dasar dalam kosmologi dan mekanika kuantum. Beliau juga aktif dalam membahas relasi antara agama dan sains. Golshani juga mengkaji tentang gagasan perlunya penafsiran sains secara Islam melalui apa yang dia sebut sebagai Sains Islam dan beliau juga mengatakan bahwa gagasan tentang sains Islam telah beredar sepanjang tiga puluh tahun terakhir. Beliau juga mendefinisikan sains Islam sebagai jenis sains yang di

2Muhammad Solihin, "Islam Dan Pemikiran Ilmiah”. Nur El-Islam, 2(1), 29-40. 2015.

${ }^{3}$ Muhammad Anshar, "Integrasi Alquran dan Sains: Suatu Perspektif Komunikasi". Jurnal Dakwah Tabligh, 18(1), 1-20. 2017. https://doi.org/10.24252/jdt.v18n1dnk08. 
dalamnya ada pengetahuan tentang dunia fisik yang terkandung dalam pandangn Islam. $^{4}$

Beberapa tokoh yang juga mengkaji dan membahas tentang berbagai hadis dan kaitannya dengan sains seperti Zaghlūl Rāghīb Muḥammad al-Najjār ${ }^{5}$ yang mencoba membuktikan kebenaran-kebenaran isi hadis dari segi sains atau ilmiahnya. Artikel yang ditulis oleh Faizin yang juga membahas secara teoretis tentang pemahaman hadis dengan sains. ${ }^{6}$ Artikel karya Erfan Soebahar dkk. yang mengkaji tentang rahasia buah kurma dan zaitun dari perspektif sains ${ }^{7}$. Tulisan Mohd Yusuf Ismail dan Abdul Kareem Toure yang mengkaji tentang kebenaran dari hadis perkembangan embrio manusia dengan sains. ${ }^{8}$

Penelitian ini bertujuan agar pembaca terutama para Umat Islam termotivasi untuk mengkaji dan meneliti serta mendalami kembali tentang isyaratisyarat sains yang telah Rasulullah sampaikan secara tersirat melalui sabdasabdanya. Tujuan lainnya adalah pada kajian ini diharapkan dapat menjadi bahan referensi bagi penulis lain untuk termotivasi menggali dan menemukan isyaratisyarat sains lainnya yang terdapat dalam hadis Nabi SAW.

Jenis penelitian ini adalah Library Research yang berarti riset kepustakaan atau kepustakaan murni. Kajian ini akan menggali konsep tentang isyarat-isyarat dalam hadis yang menggambarkan tentang sains kepada manusia dan bukti-bukti keilmiahan yang telah berhasil dibuktikan oleh pakar-pakar sains dunia.

${ }^{4}$ Syarif Hidayatullah, "Relasi Agama dan Sains Dalam Pandangan Mehdi Golshani". Jurnal Filsafat, 27(1), 65. 2017. https://doi.org/10.22146/jf.21972.

5Zaghlūl Rāghīb Muhammad al-Najjār, "al-I'jāz al-Ilmì fì al-Sunnah al-Nabawiyyah”. Dār Nahdhoh Misr. 2012.

${ }^{6}$ Benny Afwadzi, "Integrasi Ilmu-ilmu Alam dan Ilmu-Ilmu Sosial dengan Pemahaman Hadis Nabi: Telaah atas Konsepsi, Aplikasi, dan Implikasi”. Jurnal THEOLOGLA, 28(2), 351-390. 2018. https://doi.org/10.21580/teo.2017.28.2.1972.

${ }^{7}$ Muhammad Erfan Soebahar, R. Arizal Firmansyah \& Edi Daenuri Anwar, "Mengungkap Rahasia Buah Kurma dan Zaitun dari Petunjuk Hadis dan Penjelasan Sains". ULUL ALBAB Jurnal Studi Islam, 16(2), 191. 2015. https://doi.org/10.18860/ua.v16i2.3181

${ }^{8}$ Mohd Yusuf Ismail \& Abdul Kareem Toure, "Peranan sains moden dalam interaksi teks Hadis: penelitian terhadap Hadis berkaitan penciptaan janin manusia". Journal of Hadith Studies, 1(1), 12-19. 2016. 


\section{Pembahasan}

\section{Pengertian dan Urgensi Sains}

Dalam bahasa Arab kata "sains" dikenal dengan istilah "al-Ilmu". Sedangkan dalam bahasa Indonesia disebut dengan "ilmu". Secara harfiah "alIlmu" berarti segala pengetahuan, pemahaman, tanda, atau isyarat-isyarat. "alIlmu" sendiri merupakan lawan dari kata "al-jabl" (kebodohan). Dengan kata lain, semakin seseorang itu berilmu maka akan semakin jauh darinya kebodohan.

Secara istilah menurut Hasan Hito al-ilmu diartikan sebagai "Pengetahuan yang mutlak, sesuai dengan fakta, dan berdasarkan bukti (data)" Atau dengan kata lain ilmu adalah "Memahami sesuatu sesuai fakta dengan pemahaman mutlak". ${ }^{10}$ Sedangkan sains secara terminologi merupakan "Pengetahuan sistematis yang diperoleh dari suatu observasi, penelitian, dan uji coba yang mengarah pada penentuan sifat dasar atau prinsip sesuatu yang sedang diselidiki, dipelajari, dan sebagainya". ${ }^{11}$

Menurut Ziauddin Sardar ilmu atau sains adalah "Cara mempelajari alam secara obyektif dan sistematik serta ilmu merupakan suatu aktifitas manusia. Kemudian menurut John Biesanz dan Mavis Biesanz dua sarjana ilmu sosial, mereka mendefinisikan ilmu sebagai suatu cara yang teratur untuk memperoleh pengetahuan (an organized way of oftening knowledge) dari pada sebagai kumpulan teratur pada pengetahuan. Jadi ilmu merupakan suatu metode." ${ }^{\prime 2}$ Adapun Muslim A. Kadir, "Ilmu merupakan kumpulan sistematis sejumlah pengetahuan tentang alam semesta yang diperoleh melalui kegiatan berfikir". ${ }^{13}$

Sains Islam merupakan kegiatan ilmiah untuk mencari kebenaran dari suatu ilmu pengetahuan yang didasarkan pada wahyu Allah yang bersumber dari

\section{2016.}

${ }^{9}$ Huzaemah Tahido Yanggo, “Al-Qur'an Sebagi Mukjizat Terbesar”. Waratsah, 1(2), 1

${ }^{10}$ Muhammad Baqir Ya'qub, “At-Tasawwur Al-Islami Lil Ilmi Wa Atsaruhu Fi Idaratil Ma’rifah”. Majalah Islam Asia. 2011. 19-33. 2013.

${ }^{11}$ Nurmayani, "Sumbangan Islam Terhadap Sains dan Teknologi". Jurnal Handayani, 1(1),

${ }^{12}$ Warto, "Studi Islam Pendekatan Sains: Relevansi Wahyu Terhadap Ilmu Pengetahuan Modern”. International Journal Ibya' 'Ulum Al-Din, 20(2), 129-144. 2018.

${ }^{13}$ Warto, \& Abdul Jamil, "Ilmu Dalam Perspektif Filsafat Islam (Science in Perspective of Islamic Philosophy)". Ewha Journal of Social Sciences, 35(1), 1-14. 2019. https://papers.ssrn.com/sol3/papers.cfm?abstract_id=3549062 
Al-Qur'an dan Hadis Nabi dengan menggunakan metode-metode ilmu yang benar. Segala sesuatu yang bersifat fisik di dalam sains Islam dikaji tentang tujuan, kebenaran dan pengukuhannya serta segala bentuk yang dihasilkan dalam sains Islam haruslah berupa sesuatu yang bermanfaat bagi kehidupan umat manusia. ${ }^{14}$ Sains Islam memiliki perbedaan karakteristik dengan sains pada umumnya. Dalam sains Islam suatu objek yang diteliti didasarkan pada Al-Qur'an dan Hadis. Segala fenomena atau kejadian yang terjadi baik yang berkaitan dengan manusia, hewan, tumbuhan, maupun alam sekitar di telaah dengan ajran-ajaran yang terdapat dalam Al-Qur'an dan Hadis Nabi sehingga hasil dari penelitian sains Islam memiliki kualitas yang prima serta selalu sesuai dengan perkembangan zaman. ${ }^{15}$

Berdasarkan fakta di lapangan, banyak diantara ilmuan baik Muslim maupun non muslim yang mulai kembali mengkaji tentang bidang-bidang disiplin lmu pengetahuan, baik itu bidang Kedokteran, Astronomi, Fisika, Kimia, Sejarah dan lain-lain. Melalui berbagai penelitian yang dilakukan oleh para ilmuan non muslim terkadang membuat mereka semakin mengangumi Islam dan meyakini bahwa hasil penemuannya tersebut sebelum berhasil ia temukan telah temuat dalam isyarat ayat Al-Qur'an dan Hadis Nabi. Melalui penelitian yang dilakukannya juga diantara mereka terkadang memilih untuk memluk agama Islam karena Islam adalah agama yang benar dan mengatur segala aspek dari kehidupan ini. Setelah mereka masuk Islam mereka juga terus melanjutkan penelitianpenelitian lainnya yang menambah khazanah keilmuan dalam studi Al-Qur'an dan Hadis Nabi. ${ }^{16}$

Suatu ilmu dianalogikan seperti sebuah suluh yang berada dalam kegelapan yang dengan suluh tersebut dapat menerangi, memberi peunjuk dan menyelamatkan manusia dari suatu kebodohan. Dalam sebuah hadis diibaratkan:

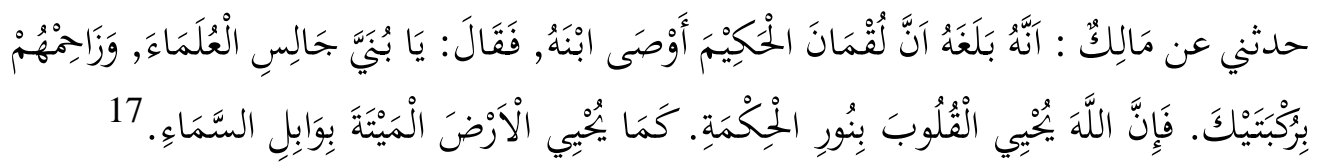

${ }^{14}$ Muhammad Taqiyuddin, \& Khoirul Umam, "Hubungan Islam dengan Sains". Unida Gontor, Universitas Darussalam Gontor, May 2016, 1-17. 2019.

${ }^{15}$ Lis Arifudin, "Integrasi Sains dan Agama serta Implikasinya Terhadap Pendidikan Islam”. Edukasia Islamika, 1(1), 171. 2016. https://doi.org/10.21927/literasi.2013.4(2).171-188

16 Ibid.,

${ }^{17}$ Muhammad Mushthafa al-A'dzhami, “Muwattha Imam Malik, Kitab: Tentang Menuntut Ilmu”. Kairo: Muassasah Zaid Al Nahyan. 2004 
"Telah menceritakan kepadaku dari Malik bahwa telah sampai padanya informasi babwa Luqman menasehati anaknya "wahai anakku tuntutlah ilmu dari para ulama. Karena sesunggubnya Allah menghidupkan hati dengan cahaya bikmah, sebagaimana bumi yang gersang disirami bujan dari langit."

Dari paparan hadis di atas dapat kita ketahui bahwa ilmu pengetahuan adalah sesuatu yang sangat dibutuhkan dalam kehidupan. Perumpaan yang disebutkan dalam hadis di atas sangatlah menarik dimana hati manusia diibaratkan dengan bumi yang gersang. Bumi yang gersang tentu saja tidak dapat menumbuhkan tanaman yang subur dan melahirkan tanaman dan bunga-bunga yang indah. Dengan adanya hujan dari langit, bumi yang gersang akan disirami sehingga tidak kering lagi dan kemudian menjadi subur karena telah terdapat usurunsur atau zat hara berkat hujan tersebut. Begitu juga dengan hati yang jika tidak disirami dengan cahaya hikmah (ilmu pengetahuan) maka hati tersebut akan menjadi mati dan tidak bisa merasakan segala sesuatu dengan baik. Dengan adanya ilmu pengetahuan akan menjadikan hati menjadi bersih dan mampu memahami berbagai hal dengan baik.

Untuk membangun sebuah peradaban yang maju maka yang perlu dilakukan adalah memajukan ilmu pengetahuan. Tidak akan maju suatu peradaban jika di dalamnya terdapat banyak kebodohan dan kebatilan. Dalam Islam ilmu menempati posisi yang sangat penting. Allah juga menjanjikan akan mengangkat derajat orang-orang yang berilmu beberapa derajat. Ketika derajat suatu kaum naik maka akan maju pula peradaban kaum tersebut. Namun jika sebaliknya kebodohan yang banyak terdapat dalam suatu kaum maka akan binasalah kaum tersebut karena kebodohannya.

\section{Motivasi Untuk Mengembangkan Sains Dalam Hadis}

Sebagai sumber hukum yang kedua dalam Islam, hadis banyak memberikan isyarat-isyarat kepada manusia untuk mengembangkan ilmu pengetahuan. Beberapa hadis yang mengisyaratkan tentang ilmu pengetahuan tersebut diantaranya adalah sebagai berikut: 
a. Hadis tentang kedudukan hukum menuntut ilmu

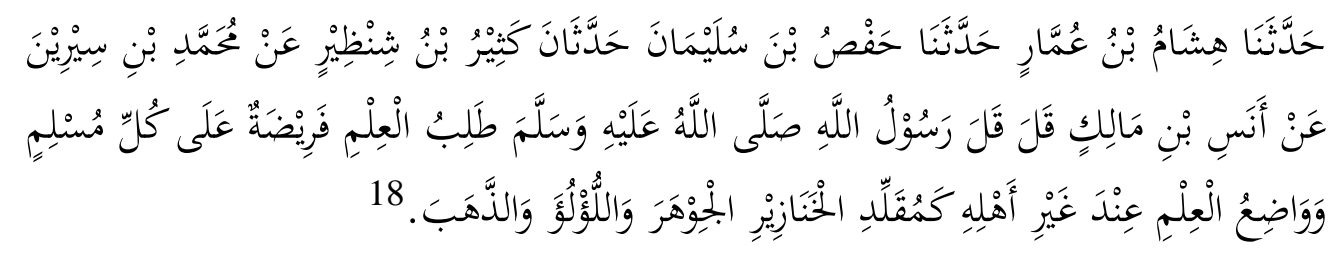

"Telab menceritakan kepada kami Hisyam bin Ammar berkata, telah menceritakan kepada kami Hafsh bin Sulaiman berkata, telah menceritakan kepada kami Katsir bin Syin₹bir dari Muhammad bin Sirin dari Anas bin Malik ia berkata; Rasulullah shallallahu 'alaibi wasallam bersabda: "Menuntut ilmu adalab kewajiban bagi setiap muslim. Dan orang yang meletakean ilmu bukan pada pada ablinya, seperti seorang yang mengalungkan mutiara, intan dan emas ke leher babi."

Dalam kitab Az-Zawaid karya Imam Al-Haitsami menyebutkan bahwa Sanad Hadis ini dhaif karena lemahnya hafsh dari Sulaiman. Imam Sayuti berkata ketika Imam Nawawi ditanya tentang kedudukan hadis ini, beliau menjawab bahwa hadis ini dhaif secara sanad walaupun secara makna hadis ini shahih. Kemudian Jamal al-Din al-Mizzi muridnya Imam Sayuti mengatakan bahwa hadis ini diriwayatkan dari banyak jalur yang bisa mencapai derajat hasan. Perkataan Imam al-Mizzi ini dibenarkan oleh gurunya yakni Imam Sayuti bahwa beliau melihat hadis ini ada 50 jalur periwayatan dan beliau telah mengumpulkannya dalam sebuah kitab kecil dan itu adalah kalamnya Imam Sayuti.

Secara garis besar hadis di atas menunjukkan perintah bagi setiap umat Islam untuk menuntut ilmu. Berkaitan dengan ilmu yang diwajibkan dalam hadis beberapa ulama memberikan penafsiran yang berbeda. Diantara ulama-ulama tersebut adalah sebagai berikut:

1) Al-Baihaqi menyebutkan mengatakan bahwa ilmu yang diwajibkan dalam hadis di atas adalah semua ilmu yang dengan ilmu itu orang dewasa tidak bertindak dalam ketidaktahuan.

2) Ibn Mubarak menyebutkan ilmu yang diwajibkan dalam hadis adalah ilmu-ilmu agama

3) Al-Baidhawi mengatakan ilmu yang dimaksud dalam hadis adalah ilmu ketuhanan dan kenabian serta peribadahan, semua itu bersifat fardu'ain.

${ }^{18}$ Muhammad Fuad Abdulbaqi, "Sunan Ibnu Majab: Mukadimah”. Kairo: Faishal Isa al- 
4) Al-Baidhawi menyebutkan ilmu yang diwajibkan dalam hadis adalah semua ilmu yang fardhu'ain yakni ilmu tentang ketuhanan dan kenabian serta peribadahan. ${ }^{19}$

Dari paparan ulama diatas dapat kita ketahui bahwa perintah dan kewajiban menuntut ilmu yang diisyaratkan dalam hadis tersebut adalah segala ilmu yang bermnfaat bagi umat manusia baik yang merupakan ilmu fardhu'ain mapun ilmu fardhu kifayah, baik ilmu dunia maupun ilmu akhirat.

Menuntut ilmu adalah kewajiban dalam agama Islam. Kewajiban ini ditujukan kepada seluruh umat Islam tanpa terkecuali. Baik laki-laki maupun perempuan, baik yang tua atau pun yang muda, dan baik yang berkedudukan tinggi maupun yang rendah semua punya kewajiban yang sama dalam hal menuntut ilmu. Dalam agama Islam tidak terdapat dikotomi ilmu yang membedakan antara ilmu agama dan ilmu bukan agama. Semua ilmu yang bermanfaat untuk kehidupan manusia haruslah senantiasa dipelajari dan dikembangkan.

Meskipun semua ilmu diwajibkan untuk dipelajari, namun dalam prosesnya haruslah melalui tahapan-tahapan sesuai dengan perkembangan dari manusia itu sendiri. Sebagaimana seorang anak yang baru lahir yang belum bisa berbicara dan mengenal sesuatu maka belum ada baginya kewajiban untuk mempelajari suatu ilmu. Namun jika anak tersebut terus hidup sampai masuk usia baligh maka sudah diwajibkan baginya untuk menuntuk ilmu agama ('ulum addin) baru kemudian disempurnakan dengan ilmu dunia ('ulum al-dunya) yang mana kedua ilmu tersebut sangat bermanfaat bagi kehidupan manusia di dunia dan akhirat.

b. Hadis tentang balasan bagi penuntut ilmu

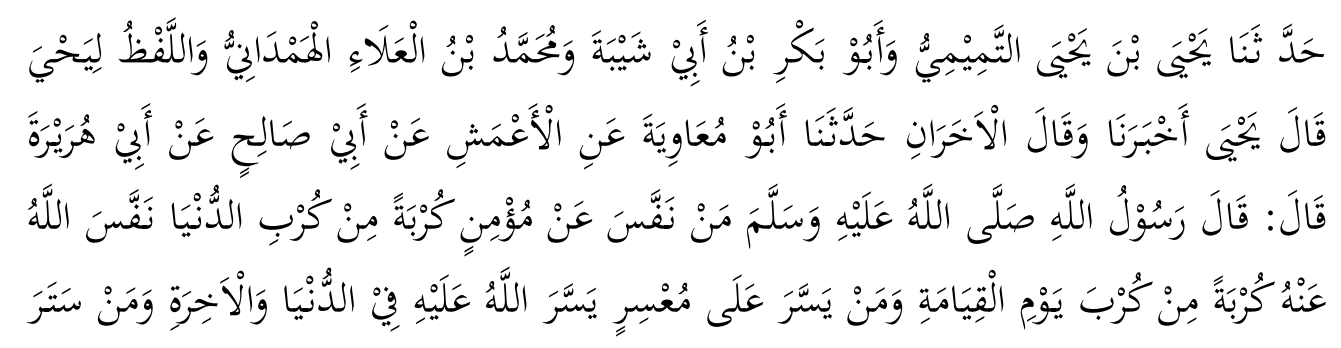

\footnotetext{
${ }^{19}$ Ahmad Darlis, "Motivasi Pengembangan Ilmu Pengetahuan dalam Perspektif Hadis Nabi”. POTENSLA: Jurnal Kependidikan Islam, 3(1), 1, 1-28. 2017. https://doi.org/10.24014/potensia.v3i1.3469
} 


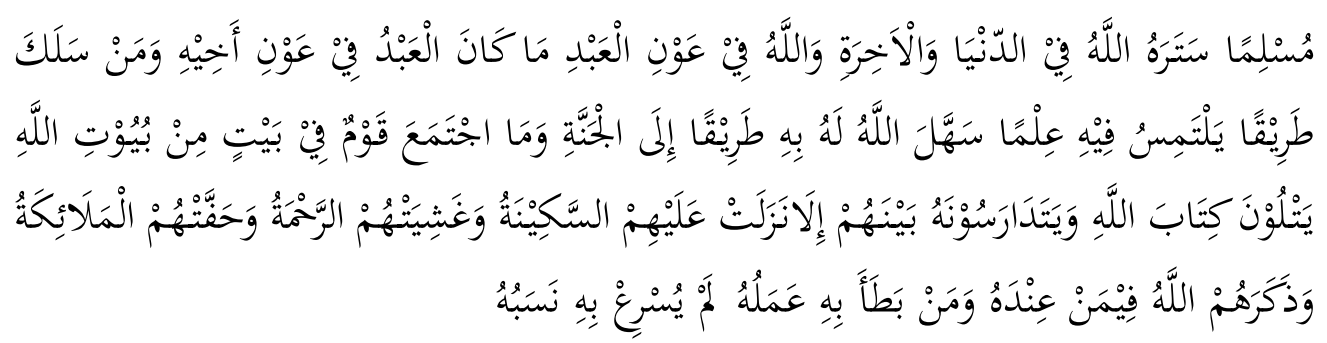

"Telah menceritakan kepada kami Yabya bin Yabya At Tamimi dan Abu Bakr bin Abu Syaibah dan Mubammad bin Al'Ala Al Hamdani-dan lafadh ini milik Yabya-dia berkata; telah mengabarkan kepada kami, dan berkata yang lainnya, telah menceritakan kepada kami Abu Mu'awiyah dari Al A'masy dari Abu Shalih dari Abu Hurairah dia berkata; Rasulullah shallallahu 'alaibi wasallam telah bersabda: 'Barang siapa membebaskan seorang mukmin dari suatu kesulitan dunia, maka Allah akan membebaskannya dari suatu kesulitan pada hari kiamat. Barang siapa memberi kemudahan kepada orang yang berada dalam kesulitan, maka Allah akan memberikan kemudahan di dunia dan akhirat. Barang siapa menutupi aib seorang muslim, maka Allah akan menutup aibnya di dunia dan akbirat. Allah akan selalu menolong hamba-Nya selama hamba tersebut menolong saudaranya sesama muslim. Barang siapa menempuh jalan untuk mencari ilmu, maka Allah akan memudabkan jalan ke surga baginya. Tidaklah sekelompok orang berkumpul di suatu masjid (rumah Allab) untuk membaca Al Qur'an, melainkan mereka akan diliputi ketenangan, rahmat, dan dikelilingi para malaikat, serta Allah akan menyebut-nyebut mereka pada malaikat-malaikat yang berada di sisi-Nya. Barang siapa yang ketinggalan amalnya, maka nasabnya tidak juga meninggikannya. ${ }^{, 20}$

Hadist di atas adalah hadist shahih riwayat Muslim yang terdapat dalam kitab Zikir, Doa, Taubat, dan Istigfar PP, Bab: Keutamaan Berkumpul Dalam Membaca Al-Qur'an dan Berzikir, Hadis nomor 2699.

Hadis di atas memberikan isyarat kepada manusia untuk mengambangkan teori berkaitan dengan ilmu pengetahuan. Al-Nawawi mengatakan bahwa hadis di atas adalah hadis yag sangat mulia karena didalamnya terdapat penjelasan tentang berbagai macam ilmu, kaidah-kaidan dan penjelasan tentang adab. Beliau juga mengatakan bahwa segala ilmu yang dipelajari harus bertujuan mencari ridho Allah SWT karena sesungguhnya "lillahi ta'ala (niat karena Allah)" adalah sayarat utama dan paling pertama ketika hendak melakukan suatu ibadah. ${ }^{21}$

${ }^{20}$ Abi al-Husain Muslim Ibn al-Hajjaj, "Kitab Shahih Muslim”. Bairut: Muassasah Risalah Nasyirun. 2016.

${ }^{21}$ Abu Zakariya Yahya Ibn Syaraf al-Nawawi, “Al-Minhäj Syarb Sbabīh Muslim Ibn Haijäj”. Kairo: Dār Ihyā al Turāts al-Arabi. 2011 
Berdasarkan kandungan hadis di atas ada beberapa hal yang memberikan makna tentang ilmu, yakni:

1) Ilmu merupakan jalan menuju surga Allah. Jika seseorang dalam menuntut ilmu diniatkan karena Allah dan mengharapkan ridho Allah SWT maka itu akan dapat memudahkan dan mendekatkan ia kepada jalan menuju surga. Ibadah yang dilandaskan ilmu akan mencapai jalan yang lurus.

2) Kemuliaan dan tingginya kedudukan ilmu dengan penuntutnya membuat malaikat membentangkan sayap-sayapnya kepada para penuntut ilmu.

3) Penduduk langit dan bumi bahkan ikan di dalam air beristigfar untuk para penuntut ilmu yang menjadi penyelemat bagi penuntut ilmu tersebut dari berbagai macam kerusakan jiwa.

Abu Bakar al-Jaza iri menyebutkan bahwa hadis di atas tidak hanya menjelasakan tentang keutamaan ilmu tetapi juga menjelaskan tentang keutamaan dari penuntut ilmu itu sendiri. Hal ini dikarenakan apabila seseorang menempuh jalan dalam menuntut ilmu maka pada hakikatnya seseorang tersebut sedang menempuh jalan menuju surga. Dan jalan menuju surga adalah suatu jalan yang benar dan membawa seseorang tersebut sampai pada tujuan hidup yang sebenarnya. ${ }^{22}$

c. Hadis keutamaan mengembangkan ilmu pengetahuan

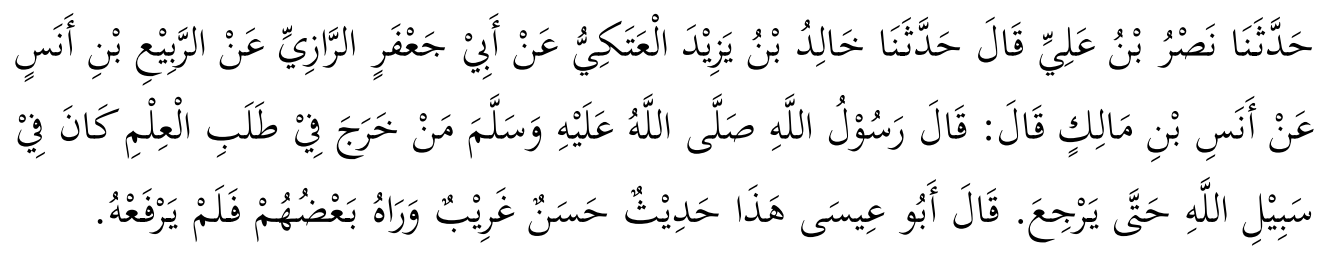

"Telah bercerita kepada kami Nahsr bin Ali dia berkata, telah bercerita kepada kami Khalid bin Yazid Al Ataki dari Abu Ja'far Ar Razi dari Ar Rabi' bin Anas dari Anas bin Malik dia berkata; Rasulullah shallallahu 'alaibi wasallam bersabda: "Barangsiapa keluar dalam rangka menuntut ilmu maka dia berada di jalan Allah sampai dia kembali." Abu Isa berkata hadis ini hasan gharib, sebagian perawi telah meriwayatkannya namun tidak merafa'kannya. ${ }^{, 23}$ 
Sebagimana yang dikatan oleh Abu Isa dalam hadis di atas bahwa status hadis tersebut adalah hasan gharib. Dengan demikian dalam suatu pembahasan hadis ini dapat dijadikan sebagai dalil.

Dalam hadis di atas disebutkan bahwa seseorang yang menuntut ilmu tergolong sama dengan orang yang berjihad di jalan Allah. Al-Mubarakfuri mengatakan bahwa "barangsiapa yang pergi dari rumah dan daerahnya untuk menuntut ilmu syariat baik fardhu'aīn maupun fardhu kifāyah, sampai dia pulang ke rumah, maka pahalanya seperti berjihad fî sabilillah." Perumpaan orang yang menuntut ilmu dengan orang yang berjihad di jalan Allah dikarenakan kedua hal tersebut pada hakikatnya adalah menghidupkan agama, menundukkan syaitan dan ketika kedua hal tersebut dilakukan kita akan merasakan lelah. Itulah kenapa orang yang menuntut ilmu digolongkan sebagai orang yang sedang berjihad dijalan Allah $\mathrm{SWT}^{24}$.

Berdasarkan paparan di atas dapat kita pahami bahwa hidupnya suatu agama sangat ditentukan oleh ilmu pengetahuan. Makin kuat dan banyak ilmu yang dimiliki oleh seseorang maka akan semakian kuat dan mendalam pula lah agamanya. Semakin banyak dan luas ilmu seseorang maka akan semakin naik juga derajatnya dihadapan Allah SWT. Dengan kata lain ilmu adalah alat untuk menaikkan kualitas dari iman dan agama seseorang. Jika ingin paham agama maka perbanyaklah ilmu pengetahuan.

\section{Beberapa Fakta Ilmiah Dari Kemukjizatan Nabi}

Prof. Dr. Zaghlul An-Najjar telah mengungkapkan fakta ilmiah dari kemukjizan hadis Nabi yang diantaranya adalah sebagai berikut ${ }^{25}$.

a. Berkaitan Dengan Bintang-Bintang Di Langit

Nabi SAW. Bersabda:

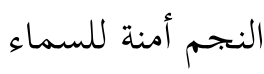

"Bintang adalah pengaman bagi langit."

Hadis di atas diriwayatkan oleh Imam Muslim dalam Shahih-nya (Kitab Fadha'il Ash-Shahabah), dengan redaksi sebagai berikut.

\footnotetext{
${ }^{24}$ Muhammad Ibn Abd al-Rahman al-Mubarakfuri, "Tuhfah al-Ahwadż Bi Syarb Jāmi" alTirmidz̨". Kairo: Dār al-Kutub al-Ilmiyah. 2011

${ }^{25}$ An-Najjar Zaghlul, "Sains Dalam Hadis, Mengungkap Fakta ilmiah dari Kemukjizatan Hadis Nabi”. Jakarta: Amzah. 2011
} 
"Kami mendapat hadis dari Abu Bakar bin Abu Syaibah, Ishaq bin Ibrabim, dan Abdullah bin Umar bin Aban; semuanya dari Husain. Abu Bakar mengatakan: kami mendapat hadis dari Husain bin Ali Al-Ja'fi, dari Mujammi' bin Yahya, dari Sa'id bin Abu Burdah, dari bapaknya, ia mengatakan: Kami shalat Maghrib bersama Rasulullah Saw. kemudian kami katakan: 'Seandainya kita duduk-duduk dan menunggu sampai kita shalat Isya' bersama beliau lagi (Si perawi mengatakan) Kami pun duduk-duduke (menunggu Isya'). Nabi Saw. lantas keluar menemui kami dan berkata: Kalian masib disini? Kami jawab, "Wahai Rasulullah, kami shalat Magbrib bersamamu.". Kemudian kami katakan, "Kami tetap duduk-duduk (di masjid) agar kami bisa shalat Isya' bersama Anda." Beliau menukas: Bagus kalian! Atau Benar kalian! Perawi menambahkan: Nabi Saw. kemudian menengadabkan kepala ke langit dan beliau memang sering menengadabkan kepala ke langit."

"Beliau lantas bersabda:"

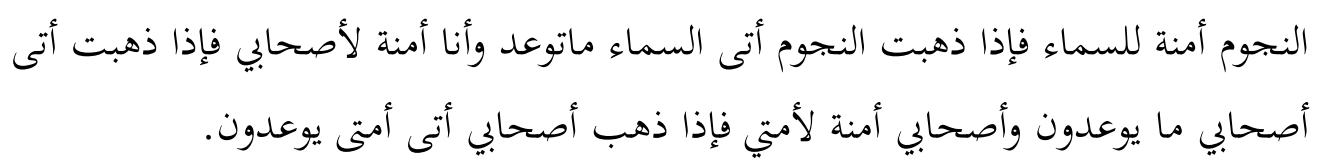

"Bintang-bintang adalah pengaman bagi langit; jika bintang mati, maka datanglah pada langit sesuatu yang mengancamnya. Dan aku adalah pengaman bagi sababatku; jika aku mati, maka datanglab kepada para sahabat sesuatu yang mengancam mereka. Sahabatku adalah pengaman umatku; jika mereka mati, maka datanglah kepada para umatku sesuatu yang mengancam mereka."

Hadis senada juga diriwayatkan oleh Imam Ahmad dalam Musnad-nya, juga diriwayatkan oleh Abu Ya'la dalam Musnad-nya dari Salamah bin Al-Akwa' dan dianggap hadis hasan oleh As-Suyuthi. Hadis ini dilansir pula oleh Al-Minawi dalam kitabnya, Faidh Al-Qadir.

Dalam hadist ini Rasulullah bersabda bahwa "Bintang adalah pengaman bagi bumi, jika bintang mati, maka datanglah pada langit sesuatu yang mengancamnya".

Kematian bintang yang dimaksud dalam hadis merupakan memudar dan meredupnya sinar dari bintang. Adapun yang dimaksud "sesuatu yang mengancam langit" merupakan terbuka, terpisah, terbagi, dan berubahnya langit menjadi sesuatu yang tidak beraturan, dipenuhi oleh kabut dan asap.

Hal ini telah dikaji secara ilmiah berdasarkan fakta-fakta kosmologis pada abad 20. Ternyata bintang merupakan salah satu benda langit yang memiliki ukuran massa serta volume yang besar, bersuhu panas yang tinggi. Bintang sendiri mengalami bebrapa fase dalam siklus hidupnya yakni dari kelahiran, lalu menjadi 
bintang muda, lalu menjadi bintang tua, kemudian cahayanya menjadi meredup dan sesudah itu meledak. Baru setelah itu menjadi kabut kembali dan kembali kesiklus pertama yakni kelahiran bintang yang baru. Inilah yang menyebabklan ketika cahaya bintang dilangit meredup maka langit akan dipenuhi oleh kabut dan asap.

Disamping itu bintang ternyata memiliki daya gravitasi yang sangat kuat yang dengan daya itu dapat mengikat bintang-bintang langit dunia satu sama lain dan bahkan dapat mengikat segala macam materi dan energi yang ada di semesta. Oleh karena itu, jika ikatan daya gravitasi yang dimiliki oleh bintang-bintang tersebut sampai lepas, maka akan berjatuhan semua bintang-bintang dan berjatuhan pula alam semesta akibat dari jatuhnya bintang-bintang tadi yang merupakan pengikatnya sebelumnya.

Di sini dapat kita lihat dengan jelas keindahan ungkapan Nabi SAW. beliau telah mengisyaratkan sejak 1.400 tahun yang lalu dengan sebegitu akurat dan ilmiah, di zaman ketika penduduk bumi masih tenggelam dengan samudera kebodohan, kegelapan, khurafat, dan mitos. Hal ini merupakan bukti jelas kebenaran kenabian, kerasulan, dan perkataan Nabi pada masa ketika orang-orang kafir dan musyrik yang menjadi mayoritas masyarakat kala itu yang selalu berusaha mengingkari kenabiannya.

b. Berkaitan Dengan Kebulatan Bumi

Nabi SAW. bersabda:

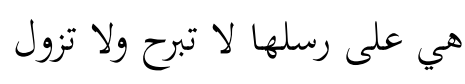

"Ia tetap berada ditempatnya, tidak berpindah dan bergeser."

Diriwayatkan dari Ibnu Abbas ra. bahwasanya Rasulullah Saw. pernah ditanya, ke mana tenggelamnya benda-benda (angkasa) yang tenggelam itu, dan dari mana terbitnya benda-benda (angkasa) yang terbit itu?

Beliau menjawab: "Ia tetap berada ditempatnya. Tidak berpindah dan bergeser. Ia tenggelam bagi satu kaum dan terbit bagi kaum yang lain. Ia terbit dan tenggelam pada suatu kaum. (dan dalam waktu bersamaan) satu kaum mengatakan ia tenggelam sementara kaum yang lain mengatakan ia terbit. (Musnad Imam Abriy Ishaq Al-Hamadaniy)".

Hadis ini menjelaskan bahwa matahari terus-menerus terbit dan terbenam saling bergantian di atas permukiman bumi. Hal ini tidak mungkin terjadi, kecuali jika bumi berbentuk bulat atau elips dan ia terus-menerus berputar mengelilingi 
porosnya di hadapan matahari sehingga terjadilah siang dan malam di atas permukaan secara bergantian. Dan ini akan berlangsung hingga kiamat tiba.

Fenomena terpenting dari kebulatan bumi adalah keragaman mathla' (posisi terbit) lantaran keragaman horizintal (cakrawala). Sehingga matahari, bulan dan benda-benda angkasa lainnya menghilang dari penduduk bumi di satu kawasan dan terbit pada penduduk kawasan lainnya. Benda-benda angkasa ini beredar pada garis orbit tertentu, tidak bergeser dan pindah sedikit pun. Persis sebagaimana firman Allah dalam QS. Yasin (36): 40):

\section{وكل في فلك يسبحون}

"Dan masing-masing beredar pada garis edarnya."

Penyampaian fakta-fakta alam ini dengan formulasi ilmiah yang cukup detail dalam kurun waktu dimana telah berkembang luas keyakinan manusia akan kedataran bumi dan ketidakbergerakannya, termasuk salah satu pancaran sinar kenabian dan risalah beliau. Tidak ada seorang pun di Semenanjung Arab pada masa diturunkan wahyu, atau bahkan berabad-abad setelahnya yang mengetahui fakta "kebulatan" bumi dan rotasinya mengelilingi porosnya di hadapan matahari.

Isyarat-isyarat ini mendorong kaum muslimin untuk mengukur luas bumi pada masa Khalifah Al-Ma'mun dengan pengukuran yang sangat teliti disertai keyakinan akan kebulatan bumi dan perputarannya mengelilingi porosnya di hadapan matahari.

Semua ini bersumber dari pancaran informasi yang dilansir dalam AlQur'an dan hadis Nabi. Keduanya sama-sama menjadi bukti kenabian dan kerasulan Nabi Muhammad SAW.

c. Berkaitan Dengan Proses Pembentukan Bumi

Diriwayatkan dari rasulullah SAW. bahwasanya beliau bersabda:

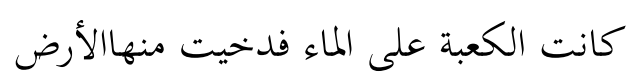

"Dabulu Ka'bah adalah bukit kecil di atas air kemudian dibentangkanlah bumi dari (bawah)nya. (An-Nibayah fi Gharib Al-Hadits wa Al-Atsar, Juz II, blm. 34-35)."

Hadis yang dianggap gharib (aneh) oleh ulama-ulama dahulu mau pun modern mengandung fakta ilmiah yang belum ditemukan manusia kecuali pada pertengahan dekade 60-an abad ke-20. Setelah usaha keras yang melibatkan ribuan 
pakar dan waktu yang cukup panjang, dibuktikanlah pada umat manusia bahwa bumi kita ini pada awal penciptaannya penuh dengan air sampai tidak ada kawasan kering yang tampak sedikit pun.

Kemudian Allah menghendaki untuk memuntahkan dasar samudera luas dengan letusan gunung berapi hebat yang terus-menerus memuntahkan lava yang menempel satu sama lain, membentuk rentetan pegunungan di tengah samudera belantara ini. Pegunungan itu terus meninggi dan meninggi sampai tampak permukaan air yang membentuk daratan pertama dalam bentuk pulau vulkanik yang mirip dengan sejumlah kepulauan vulkanik yang sekarang tersebar di seluruh samudera, misalnya kepulauan Jepang, Flipina, Indonesia, dan Hawai.

Dengan terus-menerus berlangsungnya aktivitas gunung berapi, kepulauan vulkanik pertama ini pun berkembang secara bertahap melalui proses pengembangan sehingga terbentuklah benua yang dikenal dengan Benua Pangaea.

Allah kemudian berkehendak membelah benua induk ini melalui jaringan retakan-retakan dan penyekungan bumi yang akhirnya mengakibatkan benua ini menjadi tujuh benua yang kita kenal sekarang ini. Bahkan antara satu benua dengan benua yang lain saling menjauh sampai berada pada posisinya sekarang. Proses ini dikenal dengan sebutan "siklus samudra dan daratan".

Sinyalemen Rasulullah 1,400 tahun yang lalu: Dahulu Ka'bah adalah bukit kecil di atas air kemudian dibentangkanlah bumi dari (bahwa) nya dianggap sebagai fenomena awal ilmiah yang menjadi bukti bahwa beliau menerima wahyu dari Allah dan diajar Sang Pencipta langit dan bumi karena tidak satu pun makhluk pada zaman Nabi juga beberapa abad setelahnya mengetahui fakta-fakta ini kecuali pada dekade 60-an abad ke-20.

Di luar jangkuan ilmu kasbi (kebalikan ilmu ladunni, yaitu ilmu yang diperoleh manusia malalui proses belajar) hadis ini menambahkan satu fakta ilmiah lainnya bahwa daratan di bawah Ka'bah merupakan bebatuan yang tertua di seluruh semesta. Fakta ini belum bisa dibuktikan oleh disiplin ilmu kasbi. Oleh karena itu kaum muslimin harus meneliti masalah ini dengan menentukan usia bebatuan yang ada di bawah Ka'bah melalui unsur-unsur radioaktif yang ada di sana, jika memang ada, sehingga fakta ilmiah ini dapat diajukan kepada dunia seluruhnya, muslim maupun non muslim.

Jika memang dapat dibuktikan, ini akan menjadi prasasti yang tidak terbantahkan di era sains dan teknologi sekarang ini. Juga menjadi bukti otoratif bagi seluruh manusia dan kesaksian yang menegaskan kenabian Nabi dan Rasul 
penutup Muhammad SAW. hal ini sekaligus menjadi bukti yang menegaskan kemuliaan tempat suci ini yang sengaja dipilih Allah dengan kemahatahuan-Nya yang melingkupi segala sesuatu untuk menjadi lokasi dibangunnya rumah pertama yang didirikan untuk umat manusia di muka bumi, sebagai kiblat kaum muslimin, tempat haji dan umrah. Allah pun melipatgandakan barakah tempat itu dengan menjadikan amal kebaikan di sana menjadi 100 ribu kali lipat, dan mensucikannya berikut tanahnya sejak penciptaan langit dan bumi.

Semoga shalawat kesejahteraan, salam kedamaian, dan keberkahan selalu tercurahkan kepada beliau beserta keluargs, sahabat, dan mereka yang mengikuti petunjuknya dan berdakwah di jalan-Nya sampai kiamat kelak. Segala puji bagi Allah Tuhan semesta alam.

\section{Kesimpulan}

Dari temuan yang diperoleh dapat disimpulkan bahwa dalam hadis Rasulullah terdapat banyak isyarat-isyarat yang memerintahkan kepada manusia untuk mengembangkan ilmu pengetahuan. Selain itu, terdapat keutaman ilmu, balasan dari penuntut ilmu dan temuan-temuan dalam bidang sains yang berhasil dibuktikan kebenaran berdasarkan Al-Qur'an dan Hadis.

\section{Bibliografi}

Abdulbaqi, F.M. (2011). Sunan Ibnu Majah: Mukadimah. Faishal Isa al-Halabi.

Afwadzi, B. (2018). Integrasi Ilmu-Ilmu Alam dan Ilmu-Ilmu Sosial dengan Pemahaman Hadis Nabi: Telaah atas Konsepsi, Aplikasi, dan Implikasi. Jurnal THEOLOGLA, 28(2), 351-390. https://doi.org/10.21580/teo.2017.28.2.1972

al-Hajjaj, I,M, H. (2016). Kitab Shahib Muslim. Bairut: Muassasah Risalah Nasyirun. al-A'dzhami, M.M. (2004). Muwattha Imam Malik, Kitab: Tentang Menuntut Ilmu”'. Kairo: Muassasah Zaid Al Nahyan.

al-Najjār, M.R.Z. (2012). al-Ijjāz, al-Ilmì fì al-Sunnah al-Nabawìyyah. Dār Nahdhoh Misr.

al-Nawawi, S.I.Y.Z.A. (2001). Al-Minbäj Syarh Shabīh Muslim Ibn Hajjäj”. Kairo: Dār Ihyā al Turāts al-Arabi.

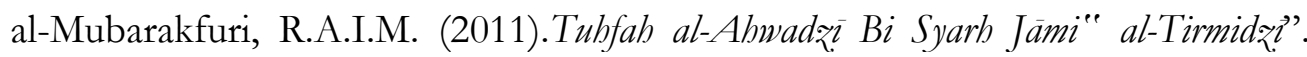
Kairo: Dār al-Kutub al-Ilmiyah. 
Anshar, M. (2017). Integrasi Alquran dan Sains: Suatu Perspektif Komunikasi. Jurnal Dakwah Tabligh, 18(1), 1-20. https://doi.org/10.24252/jdt.v18n1dnk08

Arifudin, L. (2016). Integrasi Sains Dan Agama serta Implikasinya Terhadap Pendidikan Islam. Edukasia Islamika, 1(1), 171. https://doi.org/10.21927/literasi.2013.4(2).171-188

Darlis, A. (2017). Motivasi Pengembangan Ilmu Pengetahuan Dalam Perspektif Hadis Nabi. POTENSLA: Jurnal Kependidikan Islam, 3(1), 1. https://doi.org/10.24014/potensia.v3i1.3469

Hidayatullah, S. (2017). Relasi Agama dan Sains Dalam Pandangan Mehdi Golshani. Jurnal Filsafat, 27(1), 65. https://doi.org/10.22146/jf.21972

Ismail, Y., \& Toure, K. (2016). Peranan sains moden dalam interaksi teks Hadis: penelitian terhadap Hadis berkaitan penciptaan janin manusia. Journal of Hadith Studies, 1(1), 12-19.

Nurmayani. (2013). Sumbangan Islam Terhadap Sains dan Teknologi. Jurnal Handayani, 1(1), 19-33.

Sari, R. M., \& Yudi Setiadi. (2020). Keselarasan Islam dan Sains. Ushuluna: Jurnal Ilmu Ushuluddin, 3(2), 1-26. https://doi.org/10.15408/ushuluna.v3i2.15193

Solihin, M. (2015). Islam Dan Pemikiran Ilmiah. Nur El-Islam, 2(1), 29-40.

Saefullah, A. (2001). Pelita Kehidupan Dunia dan Akbirat. Jakarta: Pustaka Azzam.

Warto. (2018). Studi Islam Pendekatan Sains: Relevansi Wahyu Terhadap Ilmu Pengetahuan Modern. International Journal Ibya' 'Ulum Al-Din, 20(2), 129_ 144.

Warto, \& Jamil, B. (2019). Ilmu Dalam Perspektif Filsafat Islam (Science in Perspective of Islamic Philosophy). Ewha Journal of Social Sciences, 35(1), 1 14. https://papers.ssrn.com/sol3/papers.cfm?abstract_id=3549062

Yanggo, T. (2016). Al-Qur'an Sebagi Mukjizat Terbesar. Waratsah, 1(2), 1-26.

Ya'qub, B. (2011). At-Tasawwur Al-Islami Lil Ilmi Wa Atsaruhu Fi Idaratil Ma'rifah. Majalah Islam Asia.

Zaghlul, N.A. (2011). Sains Dalam Hadis, Mengungkap Fakta ilmiah dari Kemukjižatan Hadis Nabi. Jakarta: Amzah. 2011 